\title{
Detection and Quantification of Airborne Claviceps purpurea sensu lato Ascospores from Hirst-Type Spore Traps using Real-Time Quantitative PCR
}

Jeremiah K.S. Dung, ${ }^{\dagger}$ Jeness C. Scott, and Qunkang Cheng, Department of Botany and Plant Pathology, Central Oregon Agricultural Research Center, Oregon State University, Madras; Stephen C. Alderman, National Forage Seed Production Research Center, United States Department of Agriculture-Agricultural Research Service, Corvallis, OR; Navneet Kaur, Department of Botany and Plant Pathology, Hermiston Agricultural Research and Extension Center, Oregon State University, Hermiston; Darrin L. Walenta, Union County Extension Service, Oregon State University, La Grande; and Kenneth E. Frost and Philip B. Hamm, Department of Botany and Plant Pathology, Hermiston Agricultural Research and Extension Center, Oregon State University, Hermiston

\begin{abstract}
The U.S. Pacific Northwest states of Oregon and Washington are major producers of cool-season grass seed. Ergot, caused by fungi in the Claviceps purpurea sensu lato group, is an important seed replacement disease of grass worldwide. Microscopic methods that are currently used to quantify airborne Claviceps ascospores captured by spore traps are not currently rapid enough to allow for detecting and reporting of spore numbers in a timely manner, hindering growers from using this information to help manage ergot. We developed a SYBR Green realtime quantitative polymerase chain reaction (qPCR)-based assay for fast and efficient detection and quantification of $C$. purpurea sensu lato ascospores from Hirst-type spore traps. Species-specificity of the qPCR assay was confirmed against 41 C. purpurea sensu lato isolates collected from six hosts and six other Claviceps spp. Significant relationships were observed between cycle threshold $(\mathrm{Ct})$ values and

standard curves of serial dilutions of DNA ranging from $1 \mathrm{pg}$ to $10 \mathrm{ng}\left(R^{2}=-0.99 ; P=0.0002\right)$ and DNA extracted from a conidial suspension representing 8 to 80,000 conidia $\left(R^{2}=-0.99 ; P=0.0004\right)$. $\mathrm{Ct}$ values from qPCR were significantly correlated with results from microscopic examination of spore trap samples from the field $(r=-0.68 ; P<0.0001)$ and the procedure was able to detect a single ascospore from spore trap tape samples. The qPCR procedure developed in this study provided a means for quantifying airborne Claviceps ascospores that was highly specific and useful over a wide range of spore densities, and could be performed in a matter of hours instead of days. The qPCR assay developed in this study could be part of an integrated pest management approach to help grass seed growers make risk-based fungicide application decisions for ergot management in grass grown for seed.
\end{abstract}

Cool-season grass seed is an important crop in the Pacific Northwest states of Oregon and Washington where, in 2012, over 300,000 acres were harvested, with a production value of over \$296 million. Kentucky bluegrass (Poa pratensis L.) and perennial ryegrass (Lolium perenne L.) are two of the major cool-season grass species grown in these two states. Ergot is an important seed replacement disease of grass and a persistent problem in grass seed production systems (Alderman 1991; Dung et al. 2016). Two species within the Claviceps purpurea sensu lato group, $C$. purpurea sensu stricto (Fr.) Tul. and $C$. humidiphila Pažoutová et M. Kolařík, can cause ergot in $P$. pratensis, whereas only $C$. purpurea sensu stricto has been reported to infect $L$. perenne (Douhan et al. 2008; Pažoutová et al. 2000; Scott et al. 2015). Soilborne sclerotia of the pathogen germinate in the spring to produce capitula which, in turn, release airborne ascospores that infect the unfertilized flowers. Once infected, the ovary is ramified by fungal hyphae and a sclerotium is formed instead of viable seed. Ergot causes economic losses to the cool-season grass seed industry due to reduced yields and the loss of viable seed and

${ }^{\dagger}$ Corresponding author: Jeremiah K. S. Dung;

E-mail: jeremiah.dung@oregonstate.edu

\section{J. K. S. Dung and J. C. Scott contributed equally to this work.}

Funding: This project was funded, in part, by the United States Department of Agriculture National Institute of Food and Agriculture, through the Western Integrated Pest Management Center (Project ID 1455). Additional funding was provided by the Agricultural Research Foundation.

*The $\boldsymbol{e}$-Xtra logo stands for "electronic extra" and indicates that one supplementary file is published online.

Accepted for publication 29 May 2018.

(c) 2018 The American Phytopathological Society increased labor costs during seed cleaning to remove sclerotia to meet certification standards.

Fungicides are an important component of an ergot management program and the majority of grass seed growers surveyed in Oregon and Washington apply fungicides at least once during anthesis (Walenta et al. 2015). However, the efficacy of fungicides depends upon the timing and coverage of the application. Fungicides that are applied after a major spore production event or do not reach the ovary will not be effective at preventing disease. Models can be used to predict when the majority of inoculum is likely to be present but pathogen populations vary daily depending on temperature, soil moisture, and other environmental factors (Dung et al. 2017). Methods to detect and quantify airborne ascospores during anthesis would provide an additional tool for growers to make more informed management decisions based upon the presence or absence of inoculum.

The ergot fungus requires unfertilized ovaries for infection; therefore, early detection and accurate quantification of airborne ascospores is imperative for successful management of ergot epidemics, especially when ascospore production coincides with anthesis. The current method used to detect and quantify Claviceps ascospores utilizes Hirst-type volumetric spore samplers, in which spores are collected on a sticky tape surface (Alderman 1993). Spore-trapping studies conducted over the past several years have proven to be useful in detecting airborne $C$. purpurea ascospores in grass seed fields (Alderman 1993; Alderman et al. 2010, 2015; Dung et al. 2017). Although spore trapping is effective at providing quantitative data on airborne spore numbers, the processing and examination of the tapes is time consuming (up to $8 \mathrm{~h}$ for a 7-day tape). The spore counting can be difficult and the amount of time and labor involved increases substantially when large numbers of ascospores are captured. This was the case during 2013, when over 9,000 ascospores were captured by a single spore trap on some days (Dung et al. 2017). Another problem encountered during the microscopic examination of spore tapes is that sections of the tape can be uncountable due to overlapping layers of pollen or high densities of soil 
particulates that can occur on dry, windy days. In addition, the potential for misidentification exists if other fungal spores with similar morphology are present, especially if the technician is not properly trained in the identification of Claviceps ascospores.

DNA-based detection methods are often considered to be more specific and sensitive than traditional microscopic identification, and less time and labor are typically involved once a protocol is developed and technicians are trained. The quantification of target DNA in the presence of extraneous spores from other species, pollen, insects, and airborne particulates can be performed more specifically and reliably. Molecular methods, mostly based on variations of polymerase chain reaction (PCR), have been used to detect many plantpathogenic fungi (Schaad and Frederick 2002), and a real-time PCR assay was previously developed for C. africana, C. sorghi, and C. sorghicola, which cause ergot of sorghum (Sorghum bicolor (L.) Moench) (Tooley et al. 2010). Spore trapping has been successfully used in combination with PCR-based methods to detect and quantify plant pathogens in air samples (Falacy et al. 2007; Klosterman et al. 2014; Kunjeti et al. 2016), demonstrating the potential value of combining spore trapping with DNA-based assays to study and monitor the production and dispersal of airborne inoculum of plant pathogens affecting important crops.

A critical component and precursor of a risk-based, integrated pest management approach to ergot management is the development of a rapid and reliable means of early detection of $C$. purpurea sensu lato inoculum. Timely and accurate forecasting and warnings of the presence of Claviceps ascospores can help growers make more informed management decisions and is recognized as a major grower priority (Walenta et al. 2015). A fast and reliable detection protocol for the presence of airborne $C$. purpurea sensu lato ascospores would better enable grass seed growers to make more informed, risk-based decisions regarding fungicide applications, potentially improving fungicide timing and efficacy, reducing the number of fungicide applications, and contributing to reduced or delayed development of fungicide resistance. Quantification of ergot inoculum during the season may also allow growers to predict which seed lots will require additional cleaning after harvest, allowing them to plan their postharvest seed conditioning operations accordingly.

Because spore traps collect spores of both pathogenic and nonpathogenic fungi, species-specificity of the assay is required to accurately detect and quantify ergot inoculum. However, both $C$. purpurea sensu stricto and $C$. humidiphila can potentially cause ergot in cool-season grass grown for seed (Douhan et al. 2008; Pažoutová et al. 2000; Scott et al. 2015); therefore, the simultaneous quantification of both species in the $C$. purpurea sensu lato group would be a useful attribute of a quantitative (q)PCR assay for ergot monitoring in grass seed production systems. The objectives of this project were to (i) develop a qPCR assay to detect and quantify inoculum of $C$. purpurea sensu lato and (ii) validate the qPCR assay using spore trap tape samples collected from commercial Kentucky bluegrass and perennial ryegrass seed production fields.

\section{Materials and Methods}

Fungal material and DNA extraction. Sclerotia of $C$. purpurea sensu lato were collected from infected perennial ryegrass in Oregon and infected Kentucky bluegrass in Oregon and Washington. Sclerotia were surface sterilized in $70 \%$ ethanol for $10 \mathrm{~s}$ followed by $0.5 \%$ $\mathrm{NaOCl}$ for $3 \mathrm{~min}$, rinsed in sterile distilled water $\left(\mathrm{sdH}_{2} \mathrm{O}\right)$, and air dried in a laminar flow hood. Isolates were obtained in pure culture by breaking surface-sterilized sclerotia in half and plating them broken-side down onto $1.5 \%$ water agar amended with streptomycin sulfate (200 mg/liter). Isolates were hyphal tipped and stored on onequarter-strength potato dextrose agar slants (Difco potato dextrose agar at $10 \mathrm{~g} /$ liter and Difco bacto agar at $15 \mathrm{~g} /$ liter; Becton, Dickinson, and Company, Sparks, MD). Sclerotia from rye (Secale cereale) and smooth brome (Bromus inermis) were collected from Oregon and Washington, respectively, and pure cultures were obtained as described above. Lyophilized tissue of $C$. purpurea from other states and countries and from other Claviceps spp. (C. africana, C. fusiformis, C. paspali, and C. pusilla) were kindly provided by Dr. Paul
Tooley, United States Department of Agriculture-Agricultural Research Service.

To obtain mycelium for the DNA extractions, isolates were grown in potato dextrose broth (Becton, Dickinson, and Company) on an orbital shaker at $150 \mathrm{rpm}$. Genomic DNA was extracted from lyophilized fungal tissue using a glass bead disruption protocol followed by phenol-chloroform extraction and sodium acetate-ethanol precipitation (Dobinson et al. 2000). The DNA pellet was subsequently resuspended in a buffered $10 \mathrm{mM}$ Tris solution. Additional DNA extracts from $C$. cynodontis and $C$. maximensis were provided by Dr. Tooley. The quality and quantity of genomic DNA was determined with a NanoDrop 2000C spectrophotometer (Thermo Fisher Scientific, Waltham, MA) and Qubit 3.0 fluorometer (Thermo Fisher Scientific), respectively, according to the manufacturer's directions.

Identification of fungal isolates. PCR was used to amplify three loci for sequencing. Primers ITS1 and ITS4 (White et al. 1990) were used to amplify the internal transcribed spacer (ITS) region of ribosomal DNA. A portion of the $\beta$-tubulin gene was amplified using primers BT5 and BT3 (Annis and Panaccione 1998; Tooley et al. 2001) and partial translation elongation factor $(\mathrm{EF})-1 \alpha$ sequences were obtained using primers EF1-728F and EF1-986R (Carbone and Kohn 1999; Tooley et al. 2001). PCR were carried out in an Eppendorf Mastercycler nexus gradient Thermal Cycler or an Eppendorf Mastercycler Gradient 5331 Thermal Cycler (Eppendorf, Hauppauge, NY).

ITS reactions were performed in $25-\mu l$ reactions containing $12.5 \mu \mathrm{l}$ of GoTaq Colorless Mastermix (2x) (Promega Corp., Madison, WI), $7.5 \mu \mathrm{l}$ of each primer $(10 \mu \mathrm{M}), 8.5 \mu \mathrm{l}$ of water, and $2 \mu \mathrm{l}$ of DNA ( $2 \mathrm{ng} / \mu \mathrm{l})$ using the following cycling parameters: denaturing at $95^{\circ} \mathrm{C}$ for $3 \mathrm{~min}$, followed by 30 cycles of denaturing at $95^{\circ} \mathrm{C}$ for $30 \mathrm{~s}$, annealing at $55^{\circ} \mathrm{C}$ for $30 \mathrm{~s}$, and extension at $72^{\circ} \mathrm{C}$ for $1 \mathrm{~min}$. A final extension step was carried out at $72^{\circ} \mathrm{C}$ for $10 \mathrm{~min}$. PCR for $\beta$-tubulin and EF-1 $\alpha$ sequences were performed in $50-\mu l$ reactions containing $10 \mu \mathrm{l}$ of GoGreen PCR Buffer (5x) (Promega Corp.), $0.4 \mu \mathrm{l}$ of dNTP $(10 \mathrm{mM})$ (Thermo Scientific), $7.5 \mu \mathrm{l}$ of each primer $(10 \mu \mathrm{M}), 1 \mu \mathrm{l}$ of $\mathrm{MgCl}_{2}$ (25 mM) (Bioline, Taunton, MA), $0.3 \mu \mathrm{l}$ of Taq polymerase $(5 \mathrm{u} / \mu \mathrm{l})$ (Promega Corp.), $0.1 \mu \mathrm{l}$ of Accuzyme $(2 \mathrm{u} / \mu \mathrm{l})$ (Bioline), $35.2 \mu \mathrm{l}$ of water, and $2 \mu \mathrm{l}$ of DNA template $(2 \mathrm{ng} / \mu \mathrm{l})$. In some cases, $\beta$-tubulin and EF- $1 \alpha$ amplicons were not obtained using the 50- $\mu$ l PCR mixture; when this occurred, $\beta$-tubulin and EF-1 $\alpha$ amplicons were obtained using the respective primers in $25-\mu 1$ PCR mixtures that were utilized to obtain ITS products as described above. PCR for $\beta$-tubulin and EF- $1 \alpha$ genes were performed using the following cycling parameters: denaturing at $95^{\circ} \mathrm{C}$ for $1 \mathrm{~min}$, followed by 35 cycles of denaturing at $94^{\circ} \mathrm{C}$ for $15 \mathrm{~s}$, annealing at $50^{\circ} \mathrm{C}$ ( $\beta$-tubulin) or $58^{\circ} \mathrm{C}(\mathrm{EF}-1 \alpha)$ for $1 \mathrm{~min}$, and extension at $72^{\circ} \mathrm{C}$ for $1 \mathrm{~min}$. A final extension step was carried out at $72^{\circ} \mathrm{C}$ for $10 \mathrm{~min}$. A 5 - $\mu \mathrm{l}$ subsample of the PCR product was analyzed by gel electrophoresis in a $1.25 \%$ agarose gel prepared with $1 \times$ Trisacetate-EDTA buffer and $1 \times$ GelRed (Biotium, Inc., Fremont, CA).

For sequencing, a 3- $\mu$ l aliquot of a 10-fold dilution of each PCR product was treated with ExoSAP-IT (USB Corporation, Cleveland, $\mathrm{OH})$, mixed with the appropriate primer, as previously described (Dung et al. 2011), and sequenced by Elim Biopharmaceuticals, Inc. (Hayward, CA). This was repeated with the corresponding primer of the pair. Paired forward and reverse sequences were quality checked, aligned, and manually edited using SeqTrace (Stucky 2012) to obtain consensus sequences.

Primer development and qPCR conditions. A SYBR Green qPCR assay was developed to amplify a 96-bp region of a $C$. purpurea sensu lato-specific random amplified polymorphic DNA (RAPD) amplicon (GenBank accession AJ252159) (Pažoutová and Tudzynski 1999; Pažoutová et al. 2000). Primer3Plus software (Untergasser et al. 2007) was used to design forward and reverse primers AJ252159-F3 (5'-AAGTGACCAAGTTGCACGTC-3') and AJ252159-R3 (5'-CAGACCGTGACAATGGTTTCTG-3'), respectively. Primer specificity was tested against the $41 C$. purpurea sensu lato isolates and 10 other Claviceps spp. described above (Table 1).

qPCR were performed in a StepOnePlus Real-Time PCR System (Thermo Fisher Scientific) in a total volume of $20 \mu \mathrm{l}$ containing $10 \mu \mathrm{l}$ of SYBR Select Master Mix (2x) (Thermo Fisher Scientific), $0.6 \mu l$ 
of each primer (10 $\mu \mathrm{M}$ each), and $1 \mathrm{ng}$ of DNA template. A notemplate water sample was included in triplicate as a negative control in each run. Cycle conditions consisted of an initial denaturing step for $10 \mathrm{~min}$ at $95^{\circ} \mathrm{C}$ followed by 40 cycles of a denaturing step for $15 \mathrm{~s}$ at $95^{\circ} \mathrm{C}$ and annealing for $1 \mathrm{~min}$ at $60^{\circ} \mathrm{C}$. A cycle threshold (Ct) value $<40$ was interpreted as a positive detection if the melting curve of the amplicon matched that of $C$. purpurea. Melting curve analysis (from $60^{\circ} \mathrm{C}$, gradually increasing $0.3^{\circ} \mathrm{C} / \mathrm{s}$ to $95^{\circ} \mathrm{C}$, with data acquisition every $1 \mathrm{~s}$ ) was used to distinguish potential primer dimers and nonspecific amplification products. Melting peaks were obtained from melting curves by plotting the negative derivative of fluorescence against temperature. All samples were amplified using three technical replicates within each run unless otherwise noted, and each run was repeated at least once.

A standard curve was developed using 10-fold serial dilutions of genomic DNA obtained from a pure culture of $C$. purpurea sensu stricto isolate Cp061. Isolate Cp061 was collected in 2013 from a commercial perennial ryegrass seed field in Umatilla County, OR. DNA was extracted from lyophilized tissue as described above. DNA was quantified with a Qubit 3.0 fluorometer and serial dilutions were performed in $\mathrm{sdH}_{2} \mathrm{O}$ to achieve a dilution series ranging from $10 \mathrm{ng}$ to $1 \mathrm{pg}$. qPCR were performed in triplicate as described above. The amplification efficiency was calculated for each run using a standard curve obtained from serial dilutions of DNA extracted from lyophilized tissue.

Table 1. Claviceps isolates and species, host and locations of origin, and mean cycle threshold (Ct) values ( \pm standard deviation [SD]) for the quantitative polymerase chain reaction assay developed in this study

\begin{tabular}{|c|c|c|c|c|}
\hline Isolate & Claviceps spp. & Host & Origin & $\mathbf{C t} \pm \mathbf{S D}^{\mathbf{a}}$ \\
\hline Cp016 & Claviceps humidiphila & Poa pratensis & Washington & $22.36 \pm 0.78$ \\
\hline Cp018 & C. humidiphila & P. pratensis & Washington & $22.63 \pm 0.26$ \\
\hline Cp019 & C. humidiphila & P. pratensis & Washington & $22.18 \pm 0.82$ \\
\hline Cp020 & C. humidiphila & P. pratensis & Washington & $22.00 \pm 0.60$ \\
\hline Cp021 & C. humidiphila & P. pratensis & Washington & $22.95 \pm 0.76$ \\
\hline $\mathrm{Cp} 022$ & C. humidiphila & P. pratensis & Washington & $22.64 \pm 0.21$ \\
\hline Cp024 & C. humidiphila & P. pratensis & Washington & $22.34 \pm 0.72$ \\
\hline Cp032 & C. humidiphila & P. pratensis & Oregon & $22.13 \pm 0.21$ \\
\hline Cp081 & C. humidiphila & P. pratensis & Washington & $21.41 \pm 0.56$ \\
\hline $\mathrm{Cp} 002$ & C. purpurea sensu stricto & Lolium perenne & Oregon & $20.66 \pm 0.86$ \\
\hline Cp003 & C. purpurea sensu stricto & L. perenne & Oregon & $21.04 \pm 0.26$ \\
\hline Cp006 & C. purpurea sensu stricto & L. perenne & Oregon & $20.14 \pm 0.43$ \\
\hline Cp008 & C. purpurea sensu stricto & L. perenne & Oregon & $20.46 \pm 0.15$ \\
\hline $\mathrm{Cp} 012$ & C. purpurea sensu stricto & L. perenne & Oregon & $20.79 \pm 0.24$ \\
\hline Cp027 & C. purpurea sensu stricto & L. perenne & Oregon & $20.83 \pm 0.30$ \\
\hline Cp036 & C. purpurea sensu stricto & L. perenne & Oregon & $20.50 \pm 0.47$ \\
\hline Cp037 & C. purpurea sensu stricto & L. perenne & Oregon & $20.68 \pm 0.04$ \\
\hline Cp040 & C. purpurea sensu stricto & L. perenne & Oregon & $20.33 \pm 0.41$ \\
\hline Cp043 & C. purpurea sensu stricto & L. perenne & Oregon & $26.77 \pm 0.15$ \\
\hline Cp049 & C. purpurea sensu stricto & L. perenne & Oregon & $20.40 \pm 0.56$ \\
\hline Cp055 & C. purpurea sensu stricto & L. perenne & Oregon & $20.69 \pm 0.34$ \\
\hline Cp057 & C. purpurea sensu stricto & L. perenne & Oregon & $27.35 \pm 1.08$ \\
\hline Cp064 & C. purpurea sensu stricto & L. perenne & Oregon & $28.10 \pm 0.24$ \\
\hline $\mathrm{Cp} 072$ & C. purpurea sensu stricto & L. perenne & Oregon & $20.62 \pm 0.14$ \\
\hline Cp085 & C. purpurea sensu stricto & L. perenne & Oregon & $19.84 \pm 0.27$ \\
\hline Cp033 & C. purpurea sensu stricto & P. pratensis & Oregon & $22.90 \pm 0.10$ \\
\hline Cp052 & C. purpurea sensu stricto & P. pratensis & Oregon & $22.38 \pm 0.30$ \\
\hline Cp053 & C. purpurea sensu stricto & P. pratensis & Oregon & $22.91 \pm 0.68$ \\
\hline Cp054 & C. purpurea sensu stricto & P. pratensis & Oregon & $19.69 \pm 0.07$ \\
\hline Cp065 & C. purpurea sensu stricto & P. pratensis & Oregon & $25.98 \pm 0.71$ \\
\hline Cp079 & C. purpurea sensu stricto & P. pratensis & Oregon & $19.82 \pm 0.08$ \\
\hline Cp030 & C. purpurea sensu stricto & Bromus inermis & Washington & $21.43 \pm 0.17$ \\
\hline Clp-1 & C. purpurea sensu stricto & Hordeum vulgare & Montana & $21.35 \pm 0.56$ \\
\hline Clp-2 & C. purpurea sensu stricto & Secale cereale & Unknown & $19.96 \pm 0.16$ \\
\hline Cp025 & C. purpurea sensu stricto & S. cereale & Oregon & $20.85 \pm 0.05$ \\
\hline Cp066 & C. purpurea sensu lato & L. perenne & Oregon & $28.65 \pm 0.16$ \\
\hline Cp014 & C. purpurea sensu lato & P. pratensis & Washington & $22.70 \pm 0.05$ \\
\hline Cp015 & C. purpurea sensu lato & P. pratensis & Washington & $23.27 \pm 0.38$ \\
\hline Cp023 & C. purpurea sensu lato & P. pratensis & Washington & $22.22 \pm 0.47$ \\
\hline Cp078 & C. purpurea sensu lato & P. pratensis & Oregon & $24.05 \pm 0.75$ \\
\hline Clp-3 & C. spartinae & Spartina sp. & New Jersey & $18.56 \pm 0.23$ \\
\hline Cls-4 & C. africana & Sorghum bicolor & India & NA \\
\hline EAP-20 & C. africana & S. bicolor & India & NA \\
\hline Ccyn & C. cynodontis & Cynodon sp. & Unknown & NA \\
\hline Clf-1 & C. fusiformis & Pennisetum typhoideum & Africa & NA \\
\hline Clf-2 & C. fusiformis & P. typhoideum & Africa & NA \\
\hline Clf-3 & C. fusiformis & P. typhoideum & Africa & NA \\
\hline Cmax & C. maximensis & Panicum maximum & Unknown & NA \\
\hline Cpas-1 & C. paspali & Paspalum sp. & North Carolina & NA \\
\hline Cpas-2 & C. paspali & Paspalum sp. & Georgia & NA \\
\hline Cpus-1 & C. pusilla & Bothriochloa sp. & Australia & NA \\
\hline Cpus-2 & C. pusilla & Dicantium sp. & Australia & NA \\
\hline
\end{tabular}

${ }^{\mathrm{a}} \mathrm{NA}=$ not amplified. 
A second standard curve was obtained using 10-fold serial dilutions of a DNA extract from a conidial suspension of isolate $\mathrm{Cp}$ 061. Conidia were washed from pure cultures grown on Claviceps medium (Gilmore et al. 2016) using sterile distilled water and quantified with a hemacytometer. DNA was extracted from the conidial suspension as described above and 10-fold serial dilutions were performed to achieve extractions representing $8 \times 10^{3}$ to $8 \times 10^{7}$ conidia $25 \mu \mathrm{l}^{-1}$. Each extraction ( $1 \mu \mathrm{l}$, representing 8 to 80,000 conidia) was used for developing the standard curve.

Spore trap samples and $q P C R$ validation. The $\mathrm{qPCR}$ assay was validated using spore trap samples from Kentucky bluegrass and perennial ryegrass fields in Oregon and Washington. Hirst-type Burkard 7-day recording volumetric spore samplers (Burkard Scientific Ltd., Uxbridge, Middlesex, UK) were used to collect airborne ascospores of $C$. purpurea sensu lato in commercial fields of perennial ryegrass (Umatilla County, OR) and Kentucky bluegrass (Jefferson County, OR; Union County, OR; and Benton County, WA). Spore samplers were also placed in artificially infested experimental plots located at the Central Oregon Agricultural Research Center (Jefferson County, OR) and the Hermiston Agricultural Research and Extension Center (Umatilla County, OR). Spore samplers were situated approximately $150 \mathrm{~m}$ from the border of commercial fields and in the center of experimental plots, with the air intake orifice located approximately at the top of the crop canopy (approximately $0.5 \mathrm{~m}$ above ground level). Spore traps were calibrated weekly to confirm that they were sampling air at 10 liters $\mathrm{min}^{-1}$. Spores and other airborne particulates were impacted onto clear Melinex tape (supplied by Burkard Scientific Ltd., Uxbridge, Middlesex, UK) coated with silicone grease (Ted Brown Associates, Los Altos, CA). In all, 64 spore trap samples obtained from April through June $2014(n=17), 2015(n=17)$, and $2017(n=30)$ were included in this study.

Tape samples from spore traps were collected and replaced every 7 days and processed as described by Alderman (1993), with minor modifications. Tapes were partitioned into daily segments and divided into hourly sections according to the manufacturer's instructions. Each daily segment of spore trap tape was cut in half lengthwise and one-half was used for microscopic quantification of ascospores while the other half was used for DNA extraction and qPCR.
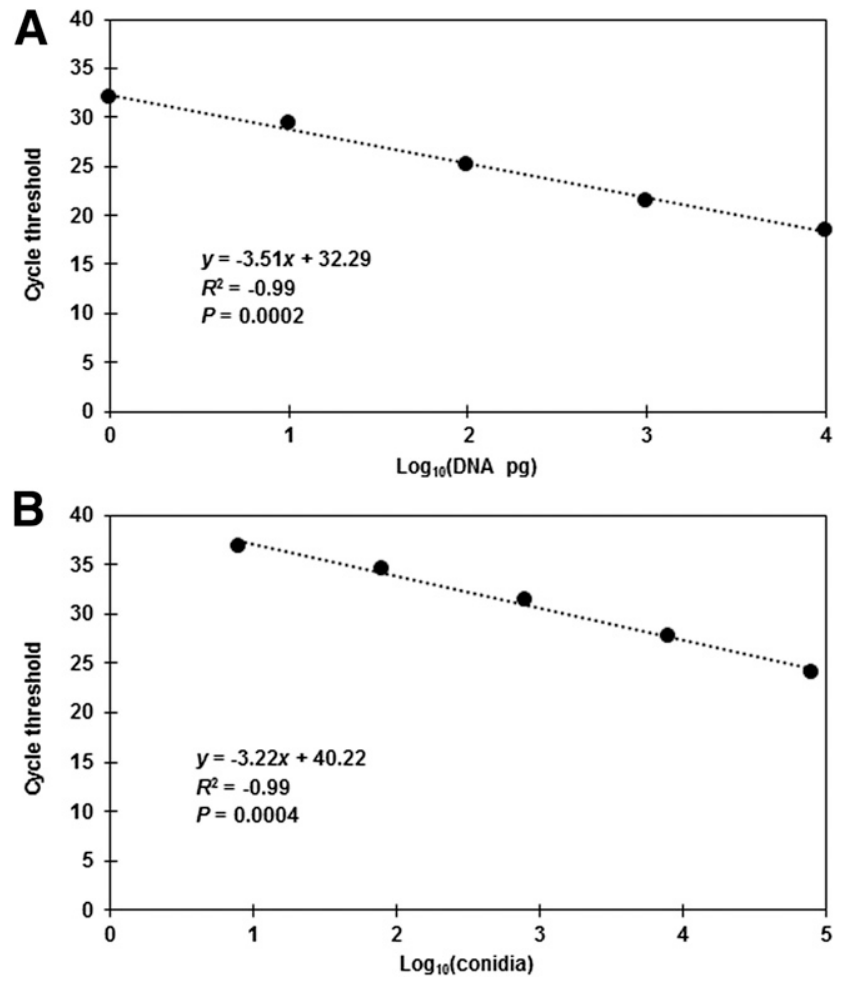

Fig. 1. Standard curve of cycle threshold values calculated from serial dilutions of DNA from $\mathbf{A}$, lyophilized tissue and $\mathbf{B}$, conidia from pure cultures of Claviceps purpurea sensu stricto.
Daily half-tape segments were mounted onto microscope slides and ascospores were stained with aniline blue solution (30 $\mathrm{mg}$ of aniline blue, $20 \mathrm{ml}$ of deionized water, $10 \mathrm{ml}$ of glycerol, and $10 \mathrm{ml}$ of $80 \%$ lactic acid). The number of ascospores trapped per hour was counted under a microscope at $\times 300$ magnification for each $24-\mathrm{h}$ period (12:00 A.M. to 11:59 P.M.) and summed to determine daily ascospore counts.

DNA was extracted from each daily half-tape segment using the extraction and precipitation method described above, with minor modifications. A $0.1 \%$ solution of IGEPAL CA-630 (MilliporeSigma, St. Louis), a nonionic and nondenaturing detergent, was added to the DNA extraction buffer $(23.9 \% \mathrm{vol} / \mathrm{vol})$ to facilitate the release of spores from the tapes (Calderon et al. 2002). $\beta$-Mercaptoethanol ( $0.3 \% \mathrm{vol} / \mathrm{vol})$ was also included in the extraction buffer to aid in the denaturing of proteins and removal of tannins and polyphenols. qPCR were performed as described above and the DNA extracted from each daily half-tape served as the template in each of four technical replicates per qPCR run. All qPCR runs were repeated once, such that eight total qPCR were performed for each daily half-tape sample.

Data analyses. Data from qPCR runs were analyzed using StepOne software (version 2.3; Thermo Fisher Scientific). Regression analysis was performed on data collected from DNA and conidia standard curve runs using PROC REG in SAS 9.4 (SAS Institute, Cary, NC). A Pearson correlation coefficient was calculated for spore counts obtained using microscopy and $\mathrm{Ct}$ values obtained from qPCR using PROC CORR in SAS. Normality and heteroscedasticity of data were tested prior to regression and correlation analyses with the Shapiro-Wilk test $(P>0.05)$ and by plotting studentized residuals using PROC UNIVARIATE and PROC PLOT in SAS.

Receiver operating characteristic (ROC) curve analysis was performed and the limit of quantification (LOQ) was determined to estimate the performance of the qPCR validation assay, as described by Nutz et al. (2011). Briefly, an ROC curve was generated by plotting sensitivity versus 1 - specificity, wherein sensitivity is the fraction of true-positive samples that score positive and specificity is the fraction of true-negative samples that score negative. For each qPCR cycle (from 28 to 40 in the dataset), the number true-positive samples with an equal or lower $\mathrm{Ct}$ value and the number of true-negative samples with higher $\mathrm{Ct}$ values were used to calculate sensitivity and specificity. The optimal cutoff point was defined as the qPCR cycle with the highest Youden index value, which was defined as sensitivity + specificity -1 (Fluss et al. 2005). ROC analysis and Youden index calculations were performed with a custom R script, v3.4.0 (R Core Team 2017). LOQ was determined as the amount of ascospores or DNA corresponding to the optimal cutoff point in the calibration curve. The quantitative relationship between the ascospore counts on spore trap tapes and $\mathrm{Ct}$ values was analyzed using logistic regression (PROC LOGISTIC) in SAS and the fitted predicted probability curves were plotted using the results from the logistic regression analysis. The limit of detection (LOD) was not calculated because of an insufficient number of data points with small quantities of ascospores in this study.

\section{Results}

Primer specificity, reaction efficiency, and LOD. The primers developed in this study were tested against 41 C. purpurea sensu lato isolates collected from six hosts, including perennial ryegrass $(n=$ $17)$, Kentucky bluegrass $(n=19)$, barley $(n=1)$, rye $(n=2)$, smooth brome $(n=1)$, and cordgrass $(n=1)$, and amplified a 96-bp product with a melting temperature between 80.7 and $81.9^{\circ} \mathrm{C}$. The mean $\mathrm{Ct}$ value was 22.11 and ranged between 18.56 and 28.65 (Table 1). The primers were specific to $C$. purpurea sensu lato, including $C$. purpurea sensu stricto, $C$. humidiphila, and $C$. spartinae, and did not amplify products from closely related isolates of $C$. africana $(n=2), C$. cynodontis $(n=1), C$. fusiformis $(n=3), C$. maximensis $(n=1), C$. paspali $(n=2)$, or $C$. pusilla $(n=2)$.

A significant relationship was observed between $\mathrm{Ct}$ values and serial dilutions of DNA derived from pure culture of isolate Cp061 $\left(R^{2}=0.99 ; P=0.0002\right)$, with $\mathrm{Ct}$ values ranging from 18.50 (10 $\mathrm{ng}$ of DNA) to 32.01 (1 pg of DNA). Ct values were also significantly related to DNA extracted from conidial suspensions of isolate 
Table 2. Detection and amount of Claviceps purpurea sensu lato ascospores observed using microscopy compared with detection and mean cycle threshold (Ct) values ( \pm standard deviation [SD]) obtained from quantitative polymerase chain reaction (qPCR) analysis of spore trap tapes collected from Kentucky bluegrass (Poa pratensis) and perennial ryegrass (Lolium perenne) seed fields

\begin{tabular}{|c|c|c|c|c|c|}
\hline Year, county, state & Grass host & Microscopy & Claviceps ascospores (n) & qPCR & $\mathrm{Ct} \pm \mathrm{SD}$ \\
\hline \multicolumn{6}{|l|}{2014} \\
\hline Union County, OR & P. pratensis & - & 0 & + & $39.37 \pm 1.77$ \\
\hline Umatilla County, OR & L. perenne & - & 0 & - & $40.00 \pm 0.00$ \\
\hline Umatilla County, OR & L. perenne & + & 6 & + & $38.83 \pm 1.28$ \\
\hline Umatilla County, OR & L. perenne & + & 7 & + & $38.71 \pm 2.70$ \\
\hline Jefferson County, OR & P. pratensis & + & 9 & + & $39.44 \pm 1.06$ \\
\hline Umatilla County, OR & L. perenne & + & 12 & - & $40.00 \pm 0.00$ \\
\hline Umatilla County, OR & L. perenne & + & 34 & + & $39.08 \pm 2.60$ \\
\hline Umatilla County, OR & L. perenne & + & 38 & + & $38.16 \pm 2.69$ \\
\hline Umatilla County, OR & L. perenne & + & 92 & - & $40.00 \pm 0.00$ \\
\hline Umatilla County, OR & L. perenne & + & 98 & - & $40.00 \pm 0.00$ \\
\hline Umatilla County, OR & L. perenne & + & 186 & + & $34.77 \pm 3.05$ \\
\hline Umatilla County, OR & L. perenne & + & 199 & + & $35.20 \pm 1.42$ \\
\hline Umatilla County, OR & L. perenne & + & 246 & + & $36.70 \pm 3.21$ \\
\hline Umatilla County, OR & L. perenne & + & 261 & + & $34.56 \pm 1.27$ \\
\hline Umatilla County, OR & L. perenne & + & 427 & + & $32.49 \pm 0.78$ \\
\hline Umatilla County, OR & L. perenne & + & 602 & + & $33.07 \pm 1.00$ \\
\hline Umatilla County, OR & L. perenne & + & 926 & + & $31.22 \pm 0.60$ \\
\hline \multicolumn{6}{|l|}{2015} \\
\hline Umatilla County, OR & L. perenne & - & 0 & + & $38.75 \pm 2.33$ \\
\hline Umatilla County, OR & L. perenne & - & 0 & + & $38.95 \pm 1.66$ \\
\hline Jefferson County, OR & P. pratensis & - & 0 & + & $39.69 \pm 0.88$ \\
\hline Jefferson County, OR & P. pratensis & + & 3 & + & $37.04 \pm 3.33$ \\
\hline Umatilla County, OR & L. perenne & + & 3 & + & $39.78 \pm 0.61$ \\
\hline Jefferson County, OR & P. pratensis & + & 7 & + & $37.98 \pm 1.79$ \\
\hline Umatilla County, OR & L. perenne & + & 15 & + & $36.00 \pm 2.97$ \\
\hline Jefferson County, OR & P. pratensis & + & 20 & + & $35.96 \pm 2.00$ \\
\hline Jefferson County, OR & P. pratensis & + & 69 & + & $38.39 \pm 1.99$ \\
\hline Umatilla County, OR & L. perenne & + & 107 & + & $36.86 \pm 6.17$ \\
\hline Umatilla County, OR & L. perenne & + & 107 & + & $39.60 \pm 0.83$ \\
\hline Jefferson County, OR & P. pratensis & + & 239 & + & $38.42 \pm 1.98$ \\
\hline Umatilla County, OR & L. perenne & + & 245 & + & $37.48 \pm 2.78$ \\
\hline Umatilla County, OR & L. perenne & + & 364 & + & $38.55 \pm 2.73$ \\
\hline Umatilla County, OR & L. perenne & + & 512 & + & $34.76 \pm 3.27$ \\
\hline Umatilla County, OR & L. perenne & + & 757 & + & $33.21 \pm 1.67$ \\
\hline Umatilla County, OR & L. perenne & + & 1054 & + & $31.73 \pm 0.50$ \\
\hline \multicolumn{6}{|l|}{2017} \\
\hline Benton County, WA & P. pratensis & - & 0 & + & $37.30 \pm 0.78$ \\
\hline Union County, OR & P. pratensis & + & 1 & + & $37.59 \pm 0.92$ \\
\hline Union County, OR & P. pratensis & + & 1 & + & $38.36 \pm 1.71$ \\
\hline Benton County, WA & P. pratensis & + & 1 & + & $38.87 \pm 1.60$ \\
\hline Benton County, WA & P. pratensis & + & 1 & + & $39.37 \pm 0.89$ \\
\hline Umatilla County, OR & L. perenne & + & 2 & + & $36.76 \pm 0.33$ \\
\hline Umatilla County, OR & L. perenne & + & 2 & + & $37.96 \pm 2.88$ \\
\hline Umatilla County, OR & L. perenne & + & 3 & + & $37.13 \pm 0.02$ \\
\hline Jefferson County, OR & P. pratensis & + & 5 & + & $36.81 \pm 1.24$ \\
\hline Umatilla County, OR & L. perenne & + & 6 & + & $35.47 \pm 1.66$ \\
\hline Jefferson County, OR & P. pratensis & + & 7 & + & $35.86 \pm 0.49$ \\
\hline Umatilla County, OR & L. perenne & + & 8 & + & $39.02 \pm 1.39$ \\
\hline Umatilla County, OR & L. perenne & + & 9 & + & $35.77 \pm 3.19$ \\
\hline Umatilla County, OR & L. perenne & + & 13 & + & $36.63 \pm 1.95$ \\
\hline Union County, OR & P. pratensis & + & 13 & + & $37.60 \pm 2.16$ \\
\hline Jefferson County, OR & P. pratensis & + & 16 & + & $34.72 \pm 1.06$ \\
\hline Union County, OR & P. pratensis & + & 17 & + & $36.53 \pm 1.55$ \\
\hline Union County, OR & P. pratensis & + & 24 & + & $36.17 \pm 0.06$ \\
\hline Jefferson County, OR & P. pratensis & + & 25 & + & $35.03 \pm 2.66$ \\
\hline Jefferson County, OR & P. pratensis & + & 29 & + & $38.00 \pm 2.18$ \\
\hline Umatilla County, OR & L. perenne & + & 29 & + & $38.16 \pm 2.60$ \\
\hline Jefferson County, OR & P. pratensis & + & 31 & + & $37.44 \pm 3.61$ \\
\hline Jefferson County, OR & P. pratensis & + & 37 & + & $37.35 \pm 3.75$ \\
\hline Jefferson County, OR & P. pratensis & + & 74 & + & $37.93 \pm 2.59$ \\
\hline Jefferson County, OR & P. pratensis & + & 79 & + & $36.24 \pm 2.06$ \\
\hline Umatilla County, OR & L. perenne & + & 100 & + & $36.82 \pm 0.35$ \\
\hline Jefferson County, OR & P. pratensis & + & 103 & + & $33.55 \pm 1.26$ \\
\hline Jefferson County, OR & P. pratensis & + & 125 & + & $35.93 \pm 1.40$ \\
\hline Umatilla County, OR & L. perenne & + & 215 & + & $34.85 \pm 1.07$ \\
\hline Umatilla County, OR & L. perenne & + & 266 & + & $35.42 \pm 0.51$ \\
\hline
\end{tabular}


Cp061 $\left(R^{2}=0.99 ; P=0.0004\right)$ and $\mathrm{Ct}$ values ranged from $23.99(8 \times$ $10^{4}$ conidia) to $36.71\left(8 \times 10^{\circ}\right.$ conidia) (Fig. 1). A strong relationship was observed between $\mathrm{Ct}$ values and serial dilutions of DNA used for standard curves among all runs $\left(R^{2}=0.979 \pm 0.005\right)$ and the $\mathrm{qPCR}$ were highly efficient among all runs $(97.6 \pm 1.5 \%)$, indicating specificity and lack of PCR inhibition in the reactions. In addition, the assay was highly sensitive and could detect as little as $1 \mathrm{pg}$ of C. purpurea sensu lato DNA and DNA obtained from as few as 8 conidia.

Melting curve analysis also confirmed that the qPCR were highly specific and generated a single product (data not shown). The melting temperature of the product amplified from isolate Cp061 was 80.72 \pm 0.10 but differences in melting temperatures were observed among C. purpurea sensu lato isolates. The mean melting temperature of the product amplified from $C$. purpurea sensu stricto isolates was greater $\left(81.13 \pm 0.08^{\circ} \mathrm{C}\right)$ than the melting temperature observed for amplicons from $C$. humidiphila isolates $\left(80.99 \pm 0.02^{\circ} \mathrm{C}\right)$; the melting temperature for the lone $C$. spartinae isolate included in this study was $81.62 \pm 0.08^{\circ} \mathrm{C}$.

qPCR validation using spore trap samples. The qPCR assay detected $C$. purpurea sensu lato in 60 of 64 samples compared with microscopic examination of slides that detected Claviceps ascospores in
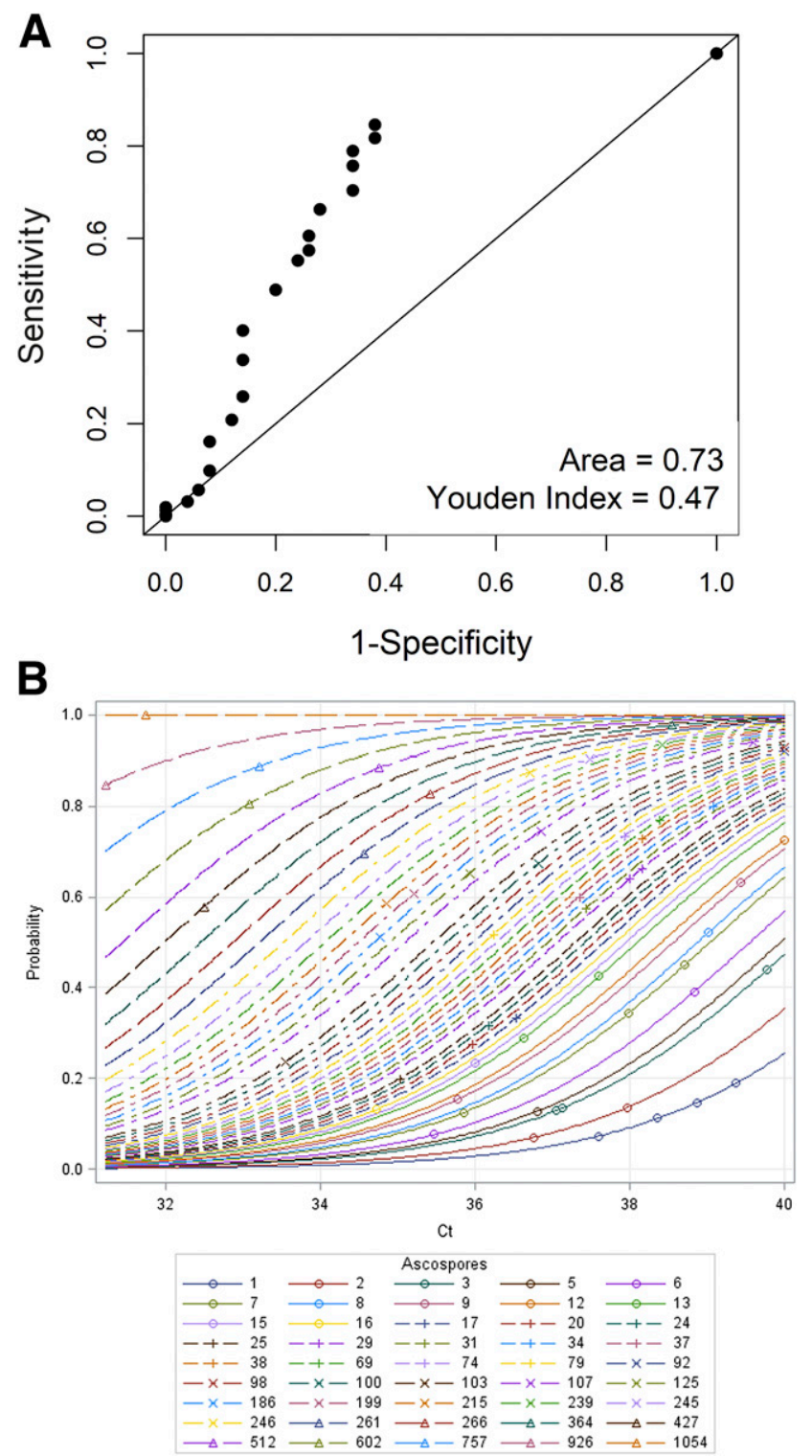

Fig. 2. A, Receiver operating characteristic curve and B, fitted predicted probability curves showing the relationship of real-time quantitative polymerase chain reaction cycle threshold (Ct) values to Claviceps purpurea sensu lato ascospores counted on spore trap tapes.
58 of 64 samples (Table 2). The range of detection for the qPCR assay was between 1 and 1,054 ascospores, with $\mathrm{Ct}$ values ranging between 39.78 and 31.22. The qPCR assay detected ascospores in five of six spore trap tape samples from which no ascospores were observed by microscopy but failed to detect ascospores in six spore trap tape samples from which ascospores were observed by microscopy; performing $\mathrm{qPCR}$ on 1:10 dilutions of DNA from these samples resulted in positive detections in three of the six samples. A significant negative correlation between $\mathrm{Ct}$ values and the number of ascospores counted using microscopy was observed when data from all three years' were combined $(r=-0.68 ; P<0.0001)$. Among individual years, significant negative correlations were observed in $2014(r$ $=-0.89 ; P<0.0001), 2015(r=-0.81 ; P<0.0001)$, and $2017(r=$ $-0.46 ; P=0.01)$.

ROC curve analysis was conducted to determine the sensitivity and specificity of the qPCR assay and determine the LOQ value of the assay. The area under the ROC curve was 0.73 (Fig. 2A) and the optimal cutoff point was a $\mathrm{Ct}$ value of 37 . The LOQ was calculated to be approximately $45 \mathrm{fg}$ of DNA and one conidium based on standard curves of DNA extracted from lyophilized tissue and conidial suspensions, respectively. The fitted probability curves of the relationship between ascospore counts from spore trap tapes and $\mathrm{Ct}$ values is shown in Figure 2B.

\section{Discussion}

A SYBR Green qPCR assay was developed for the detection and quantification of $C$. purpurea sensu lato, including $C$. purpurea sensu stricto and $C$. humidiphila, both of which can cause ergot in grass seed production systems of the Pacific Northwest. The assay could also be used to detect and quantify $C$. spartinae, a pathogen of Spartina and Distichlis grass species in coastal salt marshes (Duncan et al. 2002; Pažoutová et al. 2000, 2015).

The assay developed in this study targeted a multicopy sequencecharacterized RAPD amplicon and was highly sensitive, detecting as little as $1 \mathrm{pg}$ of DNA from pure culture and a single ascospore from spore trap tape samples collected from commercial fields. Although the multicopy nature of the target sequence can increase the sensitivity of the assay, it may also limit absolute quantification in pathogen populations with variable copy numbers of the sequence. Variation in copy number of the target sequence may have been reflected in the range of $\mathrm{Ct}$ values observed among isolates.

The qPCR method developed in this study offers many advantages over microscopic methods previously used to detect Claviceps from spore traps, including greater sensitivity, higher specificity, and shorter assay times. A conventional PCR assay was previously developed for the molecular detection of $C$. purpurea sensu lato but the pathogen could not be quantified (Tooley et al. 2001). Real-time qPCR assays have been described for $C$. africana, C. sorghi, and C. sorghicola (Tooley et al. 2010), causal agents of ergot in sorghum; but, to our knowledge, this is the first qPCR assay developed for the detection and quantification of $C$. purpurea sensu lato.

Microscopic examination of spore trap tape samples detected ergot ascospores in 58 of 64 samples collected from perennial ryegrass and Kentucky bluegrass seed fields. Claviceps ascospores were detected on five spore trap tapes from which ascospores were not observed using microscopic methods (Table 2); this could be due to the higher sensitivity of qPCR compared with traditional methods; difficulty in counting ascospores on tapes with large amounts of pollen, sand, or other debris; or unequal distribution of ascospores among the tape halves.

Based on ROC curve analysis and Youden's index, a Ct value of 37 was determined to be the optimal cutoff point for the detection of C. purpurea ascospores from spore trap tape samples. The sensitivity of this assay increased when $\mathrm{Ct}$ values greater than 37 were allowed but with a corresponding reduction in assay specificity. The SYBR Green assay developed in this study allows for the analysis of melt curves, which can be used to screen out nonspecific reactions when spore levels are low and increased sensitivity is needed. More research on ergot inoculum thresholds in grass seed crops would aid in establishing thresholds and decision-making guidelines when using this assay. 
Inhibitors may be present in spore trap tape samples with excessive amounts of soil or other natural materials that are subsequently carried over into the DNA extraction (Mahaffee and Stoll 2016). There were six spore trap tape samples from which ascospores were observed using microscopic methods but were not detected using qPCR. The reasons for these false-negative results are not known but they may have been due to excessive amounts of nontarget DNA (e.g., pollen or other fungi), PCR inhibitors in the reaction, unequal distribution of ascospores on spore trap tapes, or other factors. qPCR was repeated using a 1:10 dilution of all samples and resulted in a positive detection in three additional samples, indicating that PCR inhibitors were likely present. Regardless, a significant correlation between $\mathrm{Ct}$ values and the number of ascospores from spore trap half-tapes was observed.

Scouting for ergot with the goal of making timely management decisions is problematic because of the relatively long latent period (approximately 7 days) that occurs after infection and before the onset of symptoms (Tudzynski and Scheffer 2004). Additionally, once ergot symptoms occur, it is often too late to treat for the disease because fungicides can only prevent ovary infection by the fungus. As a result, early detection of Claviceps inoculum is important for ergot management. The ability to use molecular methods to detect low levels of inoculum (e.g., 1 to 10 spores) can help to overcome limitations inherent to spore trapping (e.g., low air sampling volumes or large amounts of soil and pollen that may make visual detection of spores difficult). Molecular methods also often require less time and labor, and the techniques used in this study are commonly used and easily transferrable to other labs. The use of qPCR to quantify Claviceps ascospores from spore traps could enable the sampling of a large number of sites over longer periods, allowing for region- or state-wide detection and forecasting programs that would otherwise be difficult to accomplish using traditional microscopic methods. If collected daily, spore trap tape samples could be processed within $24 \mathrm{~h}$, providing growers with near real-time information on ergot inoculum production and disease risk prior to and during anthesis. When used in conjunction with scouting (Dung et al. 2016) and predictive models (Dung et al. 2017), this qPCR assay for airborne $C$. purpurea sensu lato ascospores could be a component of an integrated pest management approach and help grass seed growers make risk-based fungicide application decisions for ergot management.

\section{Acknowledgments}

We thank P. W. Tooley, United States Department of Agriculture-Agricultural Research Service, for providing DNA and lyophilized tissue of Claviceps spp.; and Riverview Seed in Hermiston, OR and Columbia River Seed in Plymouth, WA for providing study sites and in-kind support.

\section{Literature Cited}

Alderman, S. C. 1991. Assessment of ergot and blind seed diseases of grasses in the Willamette Valley of Oregon. Plant Dis. 75:1038-1041.

Alderman, S. C. 1993. Aerobiology of Claviceps purpurea in Kentucky bluegrass. Plant Dis. 77:1045-1049.

Alderman, S. C., Walenta, D. L., and Hamm, P. B. 2010. Timing of occurrence of Claviceps purpurea ascospores in northeast Oregon. Online publication. Plant Health Prog. 11

Alderman, S. C., Walenta, D. L., Hamm, P. B., Martin, R. C., Dung, J., and Kosman, E. 2015. Afternoon ascospore release in Claviceps purpurea optimizes perennial ryegrass infection. Plant Dis. 99:1410-1415.

Annis, S. L., and Panaccione, D. G. 1998. Presence of peptide synthetase gene transcripts and accumulation of ergopeptines in Claviceps purpurea and Neotyphodium coenophialum. Can. J. Microbiol. 44:80-86.

Calderon, C., Ward, E., Freeman, J., and McCartney, A. 2002. Detection of airborne fungal spores sampled by rotating-arm and Hirst-type spore traps using polymerase chain reaction assays. J. Aerosol Sci. 33:283-296.

Carbone, I., and Kohn, L. M. 1999. A method for designing primer sets for speciation studies in filamentous ascomycetes. Mycologia 91:553-556.

Dobinson, K. F., Harrington, M. A., Omer, M., and Rowe, R. C. 2000. Molecular characterization of vegetative compatibility group 4A and 4B isolates of Verticillium dahliae associated with potato early dying. Plant Dis. 84:1241-1245.
Douhan, G. W., Smith, M. E., Huyrn, K. L., Westbrook, A., Beerli, P., and Fisher, A. J. 2008. Multigene analysis suggests ecological speciation in the fungal pathogen Claviceps purpurea. Mol. Ecol. 17:2276-2286.

Duncan, R. A., Sullivan, R., Alderman, S. C., Spatafora, J. W., and White, J. F. 2002. Claviceps purpurea var. spartinae var nov.: An ergot adapted to the aquatic environment. Mycotaxon 81:11-25.

Dung, J. K. S., Alderman, S. C., Kaur, N., Walenta, D. L., Frost, K. E., and Hamm, P. B. 2017. Identification of environmental factors related to Claviceps purpurea ascospore production in perennial ryegrass seed fields and development of predictive models. Plant Dis. 101:895-906.

Dung, J. K. S., Alderman, S. C., Walenta, D. L., and Hamm, P. B. 2016. Spatial patterns of ergot and quantification of sclerotia in perennial ryegrass seed fields in eastern Oregon. Plant Dis. 100:1110-1117.

Dung, J. K. S., du Toit, L. J., and Johnson, D. A. 2011. Verticillium wilt of skullcap and potential for pathogen dissemination via seeds and stems. Plant Dis. 95:1147-1152.

Falacy, J. S., Grove, G. G., Mahaffee, W. F., Galloway, H., Glawe, D. A., Larsen, R. C., and Vandermark, G. J. 2007. Detection of Erysiphe necator in air samples using the polymerase chain reaction and species-specific primers. Phytopathology 97:1290-1297.

Fluss, R., Faraggi, D., and Reiser, B. 2005. Estimation of the Youden Index and its associated cutoff point. Biom. J. 47:458-472.

Gilmore, B., Alderman, S., Knaus, B., Bassil, N., Martin, R., Dombrowski, J., and Dung, J. 2016. Simple sequence repeat markers that identify Claviceps species and strains. Fungal Biol. Biotechnol. 3:1.

Klosterman, S. J., Anchieta, A., McRoberts, N., Koike, S. T., Subbarao, K. V., Voglmayr, H., Choi, Y.-J., Thines, M., and Martin, F. N. 2014. Coupling spore traps and quantitative PCR assays for detection of the downy mildew pathogens of spinach (Peronospora effusa) and beet ( $P$. schachtii). Phytopathology 104:1349-1359.

Kunjeti, S. G., Anchieta, A., Martin, F. N., Choi, Y. J., Thines, M., Michelmore, R. W., Koike, S. T., Tsuchida, C., Mahaffee, W., Subbarao, K. V., and Klosterman, S. J. 2016. Detection and quantification of Bremia lactucae by spore trapping and quantitative PCR. Phytopathology 106:1426-1437.

Mahaffee, W. F., and Stoll, R. 2016. The ebb and flow of airborne pathogens: Monitoring and use in disease management decisions. Phytopathology 106:420-431.

Nutz, S., Döll, K., and Karlovsky, P. 2011. Determination of the LOQ in real-time PCR by receiver operating characteristic curve analysis: Application to qPCR assays for Fusarium verticillioides and F. proliferatum. Anal. Bioanal. Chem. 401:717-726.

Pažoutová, S., Olšovská, J., Linka, M., Kolínská, R., and Flieger, M. 2000 Chemoraces and habitat specialization of Claviceps purpurea populations. Appl. Environ. Microbiol. 66:5419-5425.

Pažoutová, S., Pešicová, K., Chudíčková, M., Šrůtka, P., and Kolařík, M. 2015. Delimitation of cryptic species inside Claviceps purpurea. Fungal Biol. 119:7-26.

Paßoutová, S., and Tudzynski, P. 1999. Claviceps sp. PRL 1980 (ATCC 26245), 59 and Pepty 695/ch-I: Their true story. Mycol. Res. 103:1044-1048.

R Core Team. 2017. R: A Language and Environment for Statistical Computing. Online publication. R Foundation for Statistical Computing, Vienna. https:// www.R-project.org/

Schaad, N. W., and Frederick, R. D. 2002. Real-time PCR and its application for rapid plant disease diagnostics. Can. J. Plant Pathol. 24:250-258

Scott, J. C., Kaur, N., Alderman, S. C., Walenta, D. L., Hamm, P. B., Frost, K. E., and Dung, J. K. S. 2015. Molecular differentiation of Claviceps isolates from Kentucky bluegrass and perennial ryegrass in Oregon and Washington. (Abstr.) Phytopathology 105:S4.124.

Stucky, B. J. 2012. SeqTrace: A graphical tool for rapidly processing DNA sequencing chromatograms. J. Biomol. Tech. 23:90-93.

Tooley, P. W., Carras, M. M., Sechler, A., and Rajasab, A. H. 2010. Real-time PCR detection of sorghum ergot pathogens Claviceps africana, Claviceps sorghi and Claviceps sorghicola. J. Phytopathol. 158:698-704.

Tooley, P. W., Goley, E. D., Carras, M. M., Frederick, R. D., and Weber, E. L. 2001. Characterization of Claviceps species pathogenic on sorghum by sequence analysis of the $\beta$-tubulin gene intron 3 region and EF-1 $1 \alpha$ gene intron 4. Mycologia 93:541-551.

Tudzynski, P., and Scheffer, J. 2004. Claviceps purpurea: Molecular aspects of a unique pathogenic lifestyle. Mol. Plant Pathol. 5:377-388.

Untergasser, A., Nijveen, H., Rao, X., Bisseling, T., Geurts, R., and Leunissen, J. A. M. 2007. Primer3Plus, an enhanced web interface to Primer3. Nucleic Acids Res. 35:W71-W74.

Walenta, D. L., Kaur, N., Alderman, S. C., Frost, K. E., Hamm, P. B., and Dung, J. K. S. 2015. Using information technology to advance integrated ergot disease management in perennial grass seed cropping systems. Pages 35-38 in: Seed Production Research. N. Anderson, A. Hulting, D. Walenta, M. Flowers, and C. Sullivan, eds. Ext/CrS 152, 4/16. Oregon State University, Corvallis, OR.

White, T. J., Bruns, T., Lee, S., and Taylor, J. W. 1990. Amplification and direct sequencing of fungal ribosomal RNA genes for phylogenetics. Pages 315-322 in: PCR Protocols: A Guide to Methods and Applications. M. Innis, D. Gelfand, J. Sninsky, and T. White, eds. Academic Press Inc, New York. 